\title{
Microspatial differentiation of Drosophila melanogaster populations in and around a wine cellar in southern Spain
}

\author{
Angeles ALONSO-MORAGA *, A. MUÑOZ-SERRANO *, \\ J.M. SERRADILLA * and J.R. DAVID ** \\ * Universidad de Cordoba, Departamento de Genetica \\ Av. San Alberto Magno, 14071 Cordoba, Spain \\ ** Centre National de la Recherche Scientifique, \\ Laboratoire de Biologie et Génétique Evolutives, 91190 Gif-sur-Yvette, France
}

\begin{abstract}
Summary
Allozyme polymorphism at the alcohol dehydrogenase, $\alpha$-glycerophosphate dehydrogenase and esterase-6 loci, and the variation of the third longitudinal wing vein were studied in wine cellar populations in order to test the hypothesis of a genetic differentiation of local subpopulations as a response to environmental heterogeneity. Allelic frequencies at the $A d h$ locus were clearly heterogenous over a short distance, with many more $F$ alleles among flies taken directly from the wine surface in the cellar. Flies trapped with a bait at the entrance of the cellar were intermediate in frequency, suggesting a mixing of indoor and outdoor populations. For the two other loci, no difference existed between samples taken in or out of the cellar, although in most cases a significant deficit in heterozygotes was found. For wing length, significant differences were found between samples but on the average heterozygotes had generally a bigger size. This suggests some better fitness of heterozygous flies, while the deficit of heterozygotes may be interpretated either as a Wahlund effect (Adh locus) or inbreeding for the two other loci. Selection for alcohol tolerance in the wine cellar, differential migration between indoor and outdoor populations, and a small size of subdivided populations, are proposed to explain the observed results.
\end{abstract}

Key words : microdifferentiation, Drosophila melanogaster, allozyme polymorphism, environmental heterogeneity.

\section{Résumé}

Différenciation microspatiale des populations de Drosophila melanogaster près d'une cave à vin de l'Espagne du Sud

On a étudié le polymorphisme de trois locus enzymatiques, l'alcool déshydrogénase, la glycérophosphate déshydrogénase et l'estérase 6 , ainsi que la longueur de la troisième nervure longitudinale de l'aile dans les populations autour d'une cave à vin, afin de tester l'hypothèse d'une différenciation génétique de sous-populations locales en relation avec l'hétérogénéité du milieu. Les fréquences alléliques au locus $A d h$ se sont révélées nettement différentes sur une courte distance, avec beaucoup plus d'allèles $F$ chez les mouches prises directement à la surface du vin dans la cave. Les mouches piégées avec un appât à l'entrée de la cave avaient une fréquence intermédiaire, suggérant un mélange entre une population intérieure et une population extérieure. Pour les deux autres locus, il n'y avait pas de différence de fréquence entre les échantillons pris à 
l'intérieur ou à l'extérieur, bien que l'on ait trouvé, dans la plupart des cas, un déficit d'hétérozygotes. Pour la longueur de l'aile, des différences significatives ont été trouvées entre les échantillons mais, en moyenne, les hétérozygotes avaient une plus grande taille. Ces résultats suggèrent une meilleure fitness des individus hétérozygotes, tandis que le déficit de fréquence peut être dû à un effet Wahlund (pour le locus $A d h$ ) ou à la consanguinité (pour les deux autres locus). Les résultats paraissent s'expliquer à la fois par une sélection pour la tolérance à l'alcool dans la cave à vin, par une migration différentielle entre les populations extérieures et intérieures, enfin par une petite taille de populations naturelles subdivisées.

Mots clés: microdifférenciation, Drosophila melanogaster, polymorphisme des alloenzymes, hétérogénéité de l'environnement.

\section{Introduction}

Some of the selectionist hypotheses proposed to explain the maintenance of genetic polymorphism in natural populations include ecological models relating this variability to environmental heterogeneity (LEVENE, 1953 ; LI, 1955 ; LewONTIN et al., 1978 ; Powell \& TAYLOR, 1979). According to such models, neighbouring populations may respond to environmental heterogeneity through genetic differentiation. If selection pressure is sufficiently high, the genetic differentiation of local subpopulations may take place against the uniformizing pressure of dispersal and gene flow over short distances (SlatKIn, 1987).

Wine cellar populations of $D$. melanogaster constitute a suitable experimental model to test this hypothesis. In different countries, populations collected outside and within wine cellars have been studied for allelic frequencies at the Adh locus (McKenzie \& Parsons, 1974 ; Briscoe et al., 1975; Hickey \& McLean, 1980 ; BARBANCHO et al., 1987 ; CAPY et al., 1987). In laboratory populations, it has generally been observed that ethanol treatment favors the $A d h-F$ allele (see VAN DeLDEN, 1982, for a review). Some observations, but not all, made in wine cellars match the laboratory experiments, so that further studies in different natural conditions are needed.

In a wine cellar during vintage time, two subpopulations are expected to exist : 1) the flies living and reproducing on the wine yeast surface, with a greater frequency of the $F$ allele due to the high alcoholic content of the resources; 2) those flies breeding in outdoor conditions, presumably on various fruit resources and recently migrated into the cellar. The objective of this work was to test this hypothesis of the occurrence of more or less separate subpopulations, since previous studies (AlonsoMoraga \& Muñoz-Serrano, 1986) showed that, in the Cordoba vicinity, various samples of $D$. melanogaster could exhibit very different allele frequencies at the $A d h$ locus. Two techniques of fly collection were used simultaneously within a wine cellar for discriminating these subpopulations. Also a quantitative character (wing length) which could be correlated to Adh polymorphism (PIERAGostini et al., 1981) was measured. To discard possible spurious relations, two other enzyme loci ( $\alpha-G p d h$ and Est-6) presumably not influenced by the substrate, were also studied on the same flies. Finally, allozyme polymorphism was also studied in a wild living sample, $500 \mathrm{~m}$ apart from the wine cellar. 


\section{Materials and methods}

Samples of $D$. melanogaster were taken from the wine cellar of Montemayor near Cordoba, during vintage time in September. Within the cellar, two kinds of flies were simultaneously collected. Those walking on the wine-yeast surface (W) and presumed to have performed their development on this resource, were collected with an aspirator. Other flies (T) were collected with banana traps located between 2 and $5 \mathrm{~m}$ from the previous site (see fig. 1). These traps are assumed to attract mainly outdoor flies entering the cellar. A third sample (F) was collected in the surrounding fields about $500 \mathrm{~m}$ from the cellar.

The length of the third longitudinal vein of the wing was measured in wine cellar individuals, using an eye piece micrometer (one unit $=0.4 \mathrm{~mm}$ ). Subsequently, flies were electrophoresed to study their genotypes at the Adh, $\alpha-G p d h$ and Est-6 loci using the buffer system of Poulik (1957).

Various standard statistical methods including $t$-test, Chi-square and analysis of variance, were used to analyse the data. The associations between allele and sex, genotype and sex and genotype and mode of capture were studied by means of a loglinear model for multiway tables described by UPTON (1978).

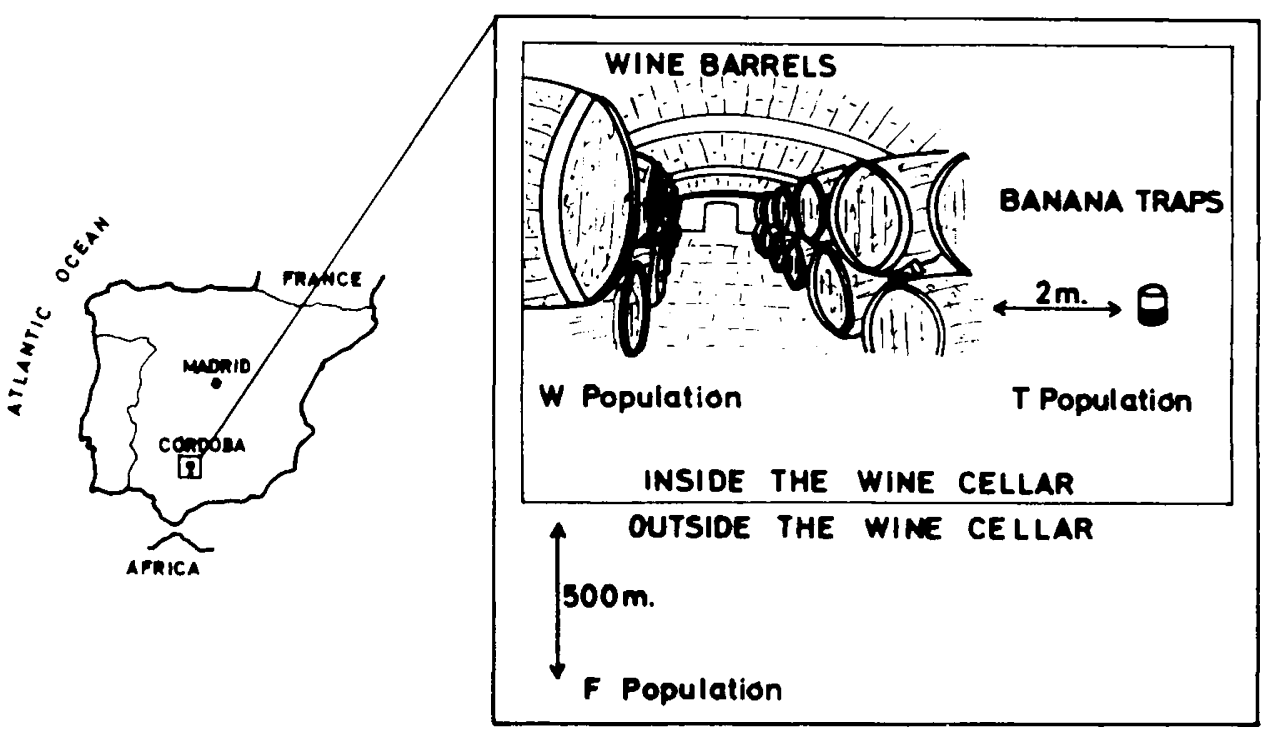

Fig. 1

Geographical location of the wine cellar and plan of the distribution of samples in the cellar. 


\section{Results}

Table 1 shows the numbers of flies of each genotype for three enzyme loci in the three samples. Departure from Hardy-Weinberg (H.W.) equilibrium was checked by Chi-square analysis. For the $A d h$ locus, two samples ( $T$ and $F$ ) are in clear disequilibrium while the third one is close to H.W. expectation. For the $\alpha-G p d h$ locus, two samples are in moderate disequilibrium (W and F) ; finally for Est-6, two samples ( $\mathrm{T}$ and F) are very close to expected frequencies and $\mathrm{W}$ sample is in moderate disequilibrium. It is interesting to note that, in all cases where the H.W. equilibrium is rejected, a deficit in heterozygotes is observed, as shown by the positive values of WrIGHT's (1951) fixation index $\mathrm{F}_{\mathrm{IT}}$.

TABLE 1

Genotypic distributions for the three enzyme loci in the three samples

\begin{tabular}{|c|c|c|c|c|c|c|c|}
\hline \multirow[b]{2}{*}{ Locus } & \multirow[b]{2}{*}{ Population } & \multicolumn{3}{|c|}{ Genotypes * } & \multirow{2}{*}{\begin{tabular}{c|} 
Allele \\
$S$ \\
frequency
\end{tabular}} & \multirow[b]{2}{*}{$F_{I T}{ }^{\dagger}$} & \multirow[b]{2}{*}{$x^{2 \ddagger}$} \\
\hline & & $F F$ & $F S$ & $S S$ & & & \\
\hline \multirow[t]{3}{*}{ Adh } & w & 256 & 65 & 6 & 0.118 & 0.043 & $0.610 \mathrm{~ns}$ \\
\hline & $\mathrm{T}$ & 42 & 9 & 20 & 0.345 & 0.719 & $36.761 P<0.001$ \\
\hline & F & 60 & 38 & 40 & 0.428 & 0.437 & $26.409 P<0.001$ \\
\hline \multirow[t]{3}{*}{$\alpha-G p d h$} & w & 115 & 137 & 75 & 0.439 & 0.149 & $7.294 P<0.01$ \\
\hline & $\mathrm{T}$ & 31 & 24 & 16 & 0.394 & 0.292 & $6.069 P<0.05$ \\
\hline & F & 55 & 49 & 34 & 0.424 & 0.273 & $10.286 P<0.01$ \\
\hline \multirow[t]{3}{*}{$\overline{E s t-6}$} & $\bar{W}$ & 54 & 127 & 146 & 0.640 & 0.156 & $8.006 P<0.01$ \\
\hline & $\mathrm{T}$ & 17 & 32 & 22 & 0.535 & 0.094 & $0.629 \mathrm{~ns}$ \\
\hline & $\mathrm{F}$ & 26 & 60 & 52 & 0.594 & 0.098 & $1.337 \mathrm{~ns}$ \\
\hline
\end{tabular}

* Number of flies for each genotype.

$\dagger$ Wright's fixation index.

$\ddagger$ Significance of departure from Hardy-Weinberg.

If we compare the allelic frequencies in the three samples, they are pretty close for $\alpha-G p d h$ and Est-6, but very different at $A d h$. More precisely a low frequency $(12 \%)$ of the $S$ allele is found in the cellar, wine breeding (W) sample and a much higher one $(43 \%)$ in the field population.

Associations between alleles or genotypes and sex were investigated according to Upton (1978). Results (not shown) were significant only for the Adh locus. More precisely, the $A d h-F$ allele was more abundant in males than in females. But, when association values were computed independently for each subpopulation, only the value for the $\mathrm{T}$ samples was significant.

Wing length was measured only in the $\mathrm{W}$ and $\mathrm{T}$ samples and results are given in table 2. As usual, we find that females are bigger than males. For each sex, a 
TABLE 2

Third longitudinal vein measurements for each sex and sampling mode

\begin{tabular}{|c|c|c|c|}
\hline & Direct (W) & Trap (T) & $t$ values \\
\hline $\begin{array}{l}\text { Male mean }( \pm \text { S.E. } \ldots \ldots \ldots \\
N \ldots \ldots \ldots \ldots \\
\text { C.V. } \ldots \ldots \ldots \ldots \ldots \ldots \ldots \ldots\end{array}$ & $\begin{array}{c}3.886 \pm 0.031 \\
134 \\
9.227\end{array}$ & $\begin{array}{c}3.635 \pm 0.056 \\
29 \\
8.294\end{array}$ & $3.508 P<0.001$ \\
\hline $\begin{array}{l}\text { Female mean }( \pm \text { S.E. }) \ldots \\
N \ldots \ldots \ldots \ldots \ldots \\
\text { C.V. } \ldots \ldots \ldots \ldots \ldots \ldots\end{array}$ & $\begin{array}{c}4.108 \pm 0.047 \\
41 \\
7.290\end{array}$ & $\begin{array}{c}4.291 \pm 0.008 \\
38 \\
11.093\end{array}$ & $2.025 P<0.05$ \\
\hline
\end{tabular}

S.E. standard error.

$N$ number of flies.

C.V. coefficient of variation.

significant difference is found between $\mathrm{W}$ and $\mathrm{T}$ flies but they are in opposite directions: $W$ males are bigger than $T$ males, while $T$ females are bigger than $W$ females. The distributions of wing lengths according to genotypes are given in table 3 . In 6 cases out of 12 , significant differences were found between genotypes. Moreover a general tendency exists, even when the variations are non-significant, for the heterozygotes to have a longer wing (8 cases out of 12). It is known (DAVID, 1979) that wing length is highly correlated to size. So, the bigger size of heterozygous flies suggests some physiological heterotic advantage which contrasts with their frequency deficit.

TABLE 3

Distributions of wing lengths and analysis of variance (ANOVA)

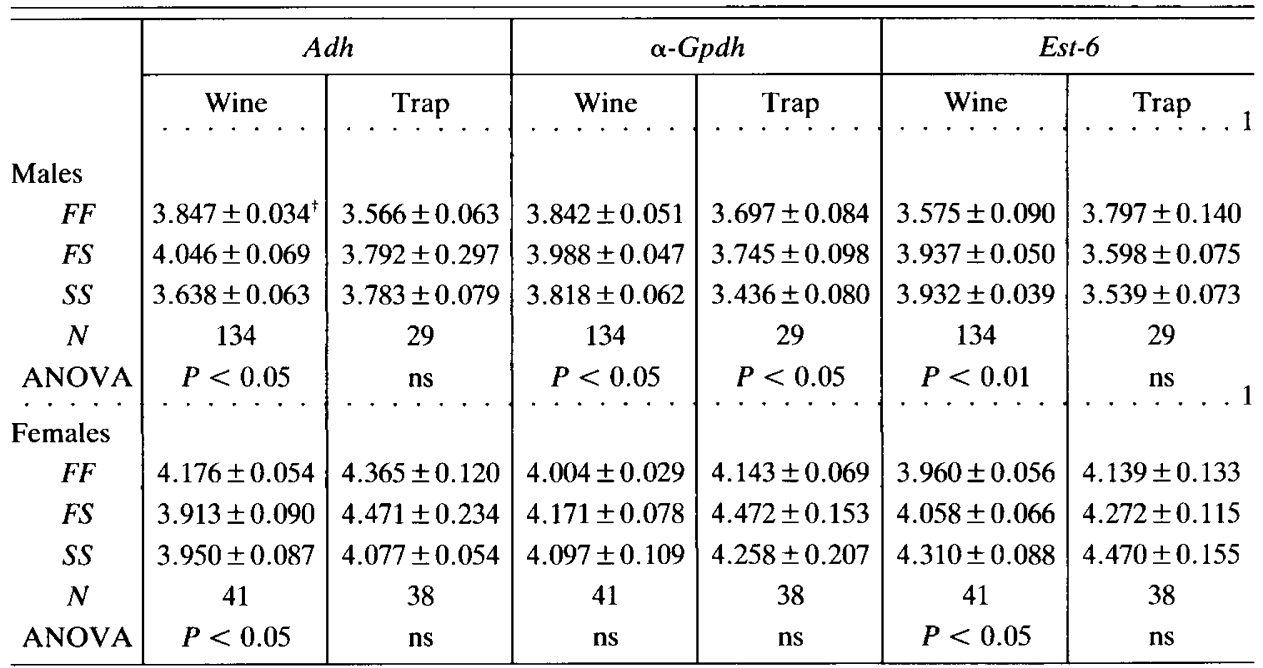

$\dagger$ Mean \pm standard deviation. 


\section{Discussion and conclusion}

The observations made around Montemayor cellar near Cordoba need to be extended over successive years before a definitive conclusion can be reached. Also comparative studies in similar ecological conditions should be undertaken. We may, however, discuss the present results to suggest some hypotheses which could be checked in further investigations.

The bigger size of heterozygotes which has been observed for three different enzyme loci suggests some physiological advantage of heterozygous genotypes, i.e. heterosis. On the other hand, in all cases where a significant departure from a H.W. equilibrium has been found, a deficit of heterozygous individuals is observed. Considering the results for body size, it is difficult to assume that such a deficit is accounted for by some selective process leading to the elimination of heterozygotes. A most likely hypothesis is to consider that the data reflect the occurrence of genetically different subpopulations. For the $A d h$ locus, we may suggest that the population breeding on the wine surface is in equilibrium and selected for a high frequency of the $F$ allele. The field population, on the other hand, would be selected for a much higher frequency of the $S$ allele, but this population does not appear to be panmictic. A possibility would be that this sample is a mixture of a cellar breeding and of a field breeding population, so that the heterozygote deficit is due to a WAHLUND effect. The interpretation of the WAHLUND effect is also valid for the sample $T$ trapped within the cellar. In this case, most flies would come from the outdoor population entering the cellar. This makes sense if we consider that adults settled on the surface of the fermenting wine are in a saturated olfactory environment and would not perceive the smell of bananas. Strikingly, a great genetic divergence is observed between samples a few metres apart. In the absence of banana traps, incoming flies are likely to move to the surface of fermenting grapes. Such migrants would not greatly modify the genetic structure of the locally breeding population if they are in small number. Direct observation showed this to be obviously the case : it was necessary to use the traps during several days to collect only 71 flies.

The heterozygote deficit at the $\alpha-G p d h$ locus is more difficult to explain, since allelic frequencies are very similar in the three samples. Fixation indices are much lower than in the case of $A d h$ and further investigations would be needed to check the constancy of this phenomenon.

It may be indicated, however, that a deficit in heterozygotes seems a common situation in nature (DANiEli \& Costa, 1977 ; NiElsen et al., 1985). A possible interpretation would be that a positive value of the fixation index reflects some inbreeding due to a patchy distribution of resources.

As suggested in the introduction, a strong environmental pressure may result in genetically subdivided and heterogeneous local populations. Such seems to be the case for the Adh locus in relation with alcoholic resources especially in the vicinity of wine cellars (Alonso-Moraga \& MuÑoz-Serrano, 1986). But this can obviously be observed only in places where selective factors are acting in opposite direction. Southern Spain appears such a favorable place for Adh since in cellars alcoholic selection is supposed to favor a high frequency, over $90 \%$ of the $F$ allele. By contrast, field populations, presumably breeding on various fruits with a low alcoholic content would reach an 
equilibrium frequency of less than $60 \%$ of $F$. Factors favoring the $S$ allele in Mediterranean countries are not known but could include temperature and desiccation or rainfall. It is interesting to note that, in other parts of the world, the genetic structure of $D$. melanogaster populations around wine cellars seems to be quite diverse. For example, McKenzie \& Parsons (1974) failed to find significant variations at the $A d h$ locus within and outside an Australian wine cellar. In France, natural populations are characterized by a very stable genetic structure at the $A d h$ locus since the frequency of the $F$ allele is almost always above $90 \%$, even in regions where there is no wine production (Girard \& Palabost, 1976 ; David, 1982 ; Charles-Palabost et al., 1985 ; CAPY et al., 1987) suggesting that such high equilibrium frequency results from something other than ethanol selection.

Finally, D. melanogaster populations appear to be a good model for studying not only long distance variations but also microspatial differentiation, habitat selection, dispersal and gene flow. According to the place of study, identical alleles such as those found at the Adh locus (KreItMan, 1980) could be involved in different systems of local environmental pressure resulting in divergent adaptations. Extensive studies over successive years in distant localities with different climates are needed to check such an hypothesis.

Received July 22, 1987. Accepted November 18, 1987.

\section{References}

Alonso-Moraga A., Muñoz-Serrano A., 1986. Allozyme polymorphism and linkage disequilibrium of $A d h$ and $\alpha-G p d h$ loci in wine cellar and field populations of Drosophila melanogaster. Experientia, 42, 1048-1050.

Barbancho M., Sanchez-Canete F.J.S., Dorado G., Pineda M., 1987. Relation between tolerance to ethanol and alcohol dehydrogenase (ADH) activity in Drosophila melanogaster: selection, genotype and sex effects. Heredity, 58, 443-450.

Briscoe D.A., Robertson A., Malpica J.M., 1975. Dominance at $A d h$ locus in response of adult Drosophila melanogaster to environmental alcohol. Nature, 255, 148-149.

Capy P., David J.R., Carton Y., Pla E., Stockel J., 1987. Grape breeding Drosophila communities in Southern France : short range variation in ecological and genetical structure of natural populations. Acta. Oecol., Oecol. Gener., 8, 435-440.

Charles-Palabost L., Lehmann M., Merçot H., 1985. Allozyme variation in fourteen natural populations of Drosophila melanogaster collected from different regions of France. Génét. Sél. Evol., 17, 201-210.

DaniEli G.A., Costa R., 1977. Transient equilibrium at the Est-6 locus in wild populations of Drosophila melanogaster. Genetica, 47, 37-41.

DAvid J.R., 1979. Utilization of morphological traits for the analysis of genetic variability in wild populations. Aquilo, Ser. Zool., 90, 49-61.

DAvid J.R., 1982. Latitudinal variability of Drosophila melanogaster. Allozyme frequencies divergence between European and Afrotropical populations. Biochem. Genet., 20, 747-761.

Girard P., Palabost L., 1976. Study of the enzymatic polymorphism of 15 natural populations of Drosophila melanogaster. Arch. Zool. Exp. Gen., 117, 41-55.

Hickey D.A., McLean M.D., 1980. Selection for ethanol tolerance and Adh allozymes in natural populations of Drosophila melanogaster. Genet. Res., 36, 11-15. 
KreItMan M., 1980. Assessment of variability within electromorphs of alcohol dehydrogenase in Drosophila melanogaster. Genetics, 95, 467-475.

LEVENE J., 1953. Genetic equilibrium when more than one ecological niche is available. Am. Nat., 87, 331-333.

Lewontin R.C., Ginzburg L.R., Tuluapurjar S.D., 1978. Heterosis as an explanation for large amounts of genic polymorphism. Genetics, 88, 149-170.

L1 C.C., 1955. Population genetics. 366 p., Univ. Chicago Press, Chicago.

McKenzie J.A., Parsons P.A., 1974. Microdifferentiation in natural population of Drosophila melanogaster to alcohol in the environment. Genetics, 77, 385-394.

Nielsen K.M., Hoffmann A.A., McKechnie S.W., 1985. Population genetics of the metabolically related Adh, $\alpha-G p d h$ and Tpi polymorphisms in Drosophila melanogaster. 2. Temporal and spatial variation in an orchard population. Génét. Sél. Evol., 17, 41-58.

Pieragostini E., Sangiorgi S., Giorgi G., Cavicchi S., 1981. Mimicry of isozyme adaptative advantage by gene association. 1. Relationship between $A d h$ genotypes and body dimension in Drosophila cage populations : a multivariate analysis. Genetica, 56, 27-37.

Poulik M.D., 1957. Starch gel electrophoresis in a discontinuous system of buffer. Nature, 180, 1477-1478.

Powell J.R., TAYlor C.E., 1979. Genetic variation in ecologically diverse environments. Amer. Scientist, 67, 590-596.

SLATKIN M., 1987. Gene flow and the geographic structure of natural populations. Science, 236, 787-792.

UpTON G.J.G., 1978. The analysis of cross-tabulated data. 148 p., John Wiley \& Sons, New York.

VAN Delden W., 1982. The alcohol dehydrogenase polymorphism in Drosophila melanogaster. Evol. Biol., 15, 187-222.

WRIGHT S., 1951. The genetical structure of populations. Ann. Eugen., 15, 323-354. 